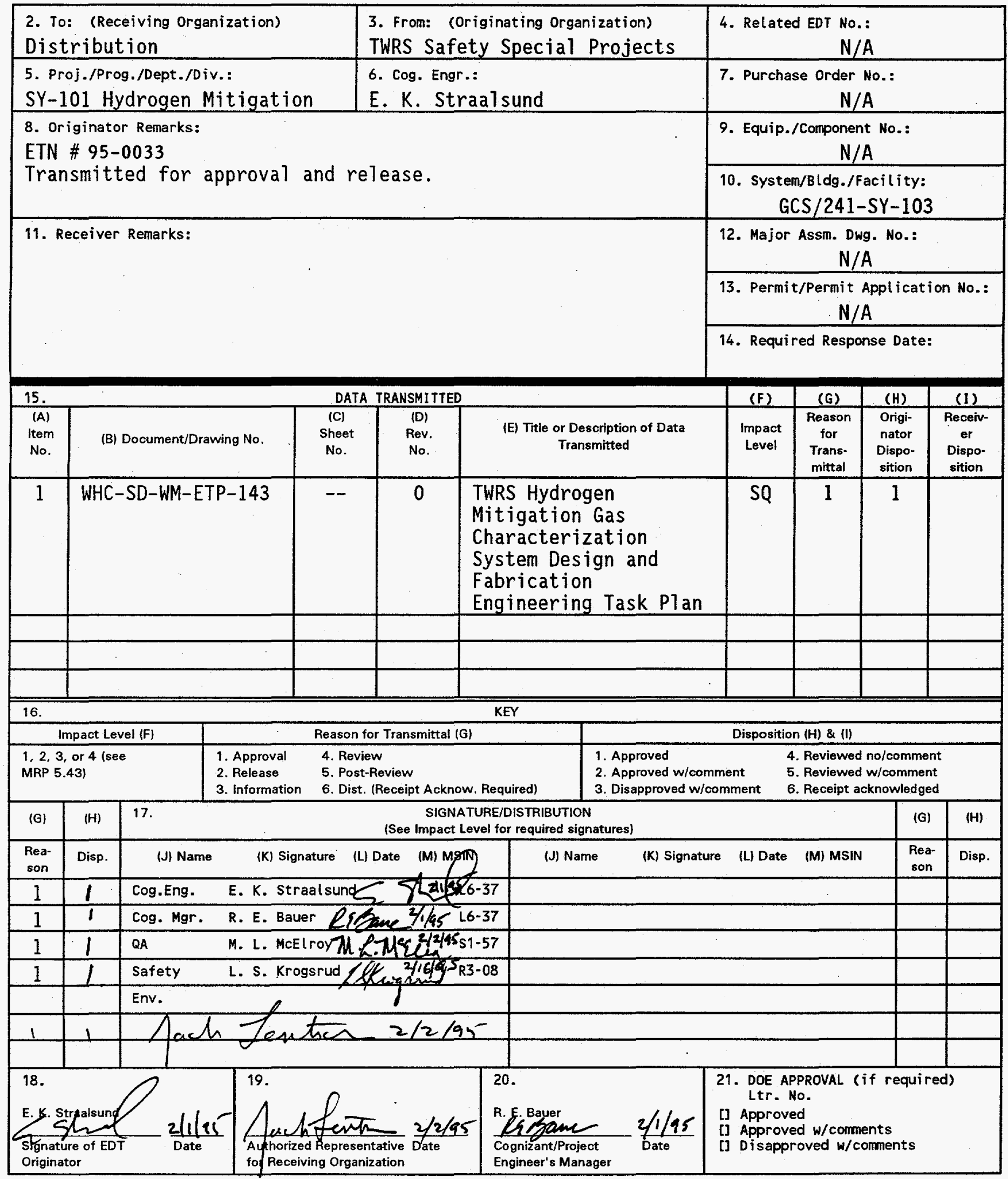




\section{DISTRIBUTION SHEET}

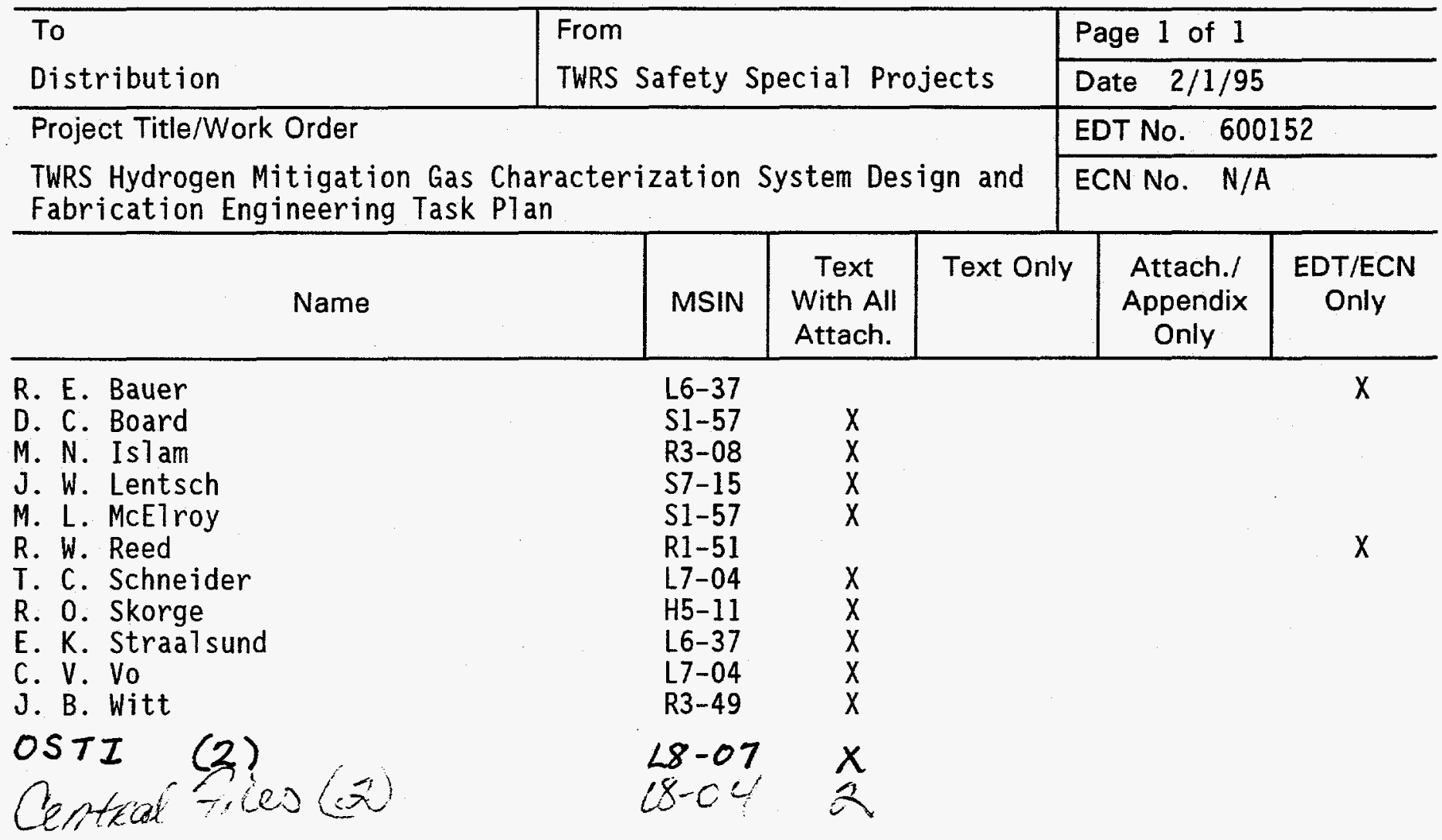




\section{DISCLAIMER}

Portions of this document may be illegible in electronic image products. Images are produced from the best available original document. 


\section{REVIEW COMMENT RECORD (RCR)}

\begin{tabular}{|c|c|}
\hline $\begin{array}{l}\text { 1. Date } \\
\text { January } 26,1995 \\
\end{array}$ & $\begin{array}{r}\text { 2. Review No. } \\
73.95\end{array}$ \\
\hline $\begin{array}{l}\text { 3. Project No. } \\
\text { ETP-143 }\end{array}$ & 4. Page \\
\hline
\end{tabular}

5. Document Number(s)/Title(s)

TWRS hydrogen Mitigation Gas Characterization System Design and Fabrication Engineering Task Plan, WHC-SD-W-ETP-143, DRAFT

\section{Program/Project/} Building Number

TWRS

\author{
7. Reviewer \\ J. E. Pieper
}

8. Organization/Group

TWRS Rad. Con. Tech. Support
9. Location/Phone

$200 \mathrm{E} / 2751 \mathrm{E} / \mathrm{A} 121$ $376-4175$
17. Comment Submittal Approval:

Organization Manager (Optional)

\begin{tabular}{l}
\hline 12. \\
\hline 1 \\
\hline 2 \\
\hline
\end{tabular}
Control." as needed.
10. Agreement with indicated comment disposition(s)

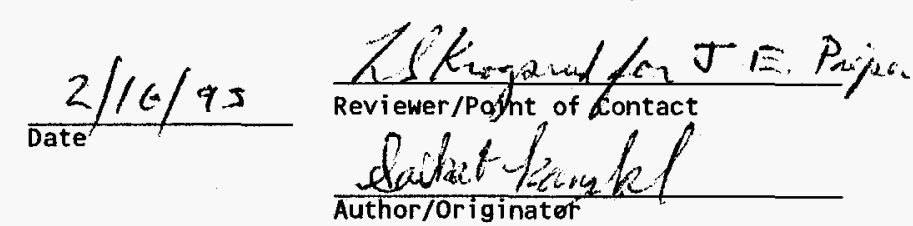

11. CLOSED

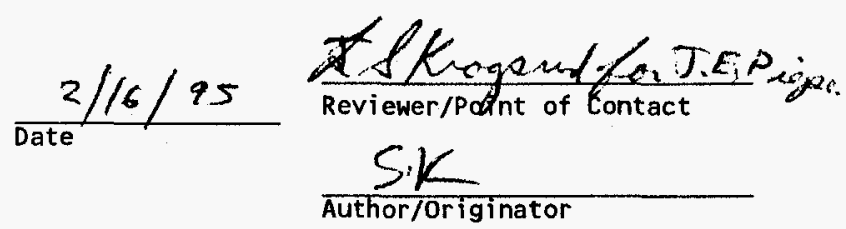

13. Comment(s)/Discrepancy(s) (Provide technical justification for the comment and detailed recommendation of the action required to correct/ resolve the discrepancy/problem indicated.)

1 Section 4.5, third bullet : Please reword to read "..Fire Safety, Nuclear Safety and Radiological

2 Page 9 : I recommend adding "4.8 TWRS Radiological Control, Cognizant manager : Jim Shelor ;1) Provide Health Physics Technician field support 2) prepare Radiological Work Permit and ALARA Management Work Sheet. 3) Provide Radiological Engineering support

\begin{tabular}{|l|l|l}
\hline $\begin{array}{l}\text { 14. } \\
\text { Poid } \\
\text { Point }\end{array}$ & 15. Disposition (Provide justification if NOT accepted.) & $\begin{array}{l}16 . \\
\text { status }\end{array}$ \\
\hline & $\begin{array}{l}\text { Accept. Comment will be incorporated } \\
\text { revised to only cover design and fabrication } \\
\text { tasks. A separate ETP will be issued to } \\
\text { address field installation, operation, and } \\
\text { maintenance of the GCS. Will add the } \\
\text { recommended responsibilities to that } \\
\text { document. }\end{array}$ & \\
\hline
\end{tabular}




\section{RELEASE AUTHORIZATION}

Document Number: WHC-SD-WM-ETP-143, ReV. 0

Document Title: TWRS HYDROGEN MITIGATION GAS CHARACTERIZATION SYSTEM DESIGN AND FABRICATION ENGINEERING TASK PLAN

Release Date: $\quad 3 / 1 / 95$

This document was reviewed following the
procedures described in WHC-CM-3-4 and is:

APPROVED FOR PUBLIC RELEASE

WHC Information Release Administration Specialist:

(thies Millieghand

C. Willingham

$3 / 1 / 95$

TRADEMARK DISCLAIMER. Reference herein to any specific commercial product, process, or service by trade name, trademerk, manufacturer, or otherwise, does not necesserily constitute or imply its endorsement, recommendation, or favoring by the United states Government or any agency thereof or its contractors or subcontractors.

This report has been reproduced from the best available copy. Aveilable in paper copy and microfiche. Printed in the United States of America. Available to the U.S. Department of Energy and its contractors from:

U.S. Department of Energy

Office of Scientific and Technical Information (OSTI)

P.0. Box 62

Oak Ridge, TM 37831

Telephone: (615) 576-8401

Available to the public from:

U.S. Depertment of Camberce

National Technical Information Service (NTIS)

5285 Port Royel Rosd

Springfield, va 22161

Telephone: (703) 487-4650 


\section{SUPPORTING DOCUMENT}

1. Total Pages 11

2. Title

3. Number

TWRS Hydrogen Mitigation Gas Characterization System Design and Fabrication Engineering Task PTan

5. Key Words

Gas Characterization

103-SY

Engineering Task Plan

Hydrogen Mitigation

WHC-SD-WM-ETP-143

4. Rev No.

0

6. Author

Name: E. K. Straałsund

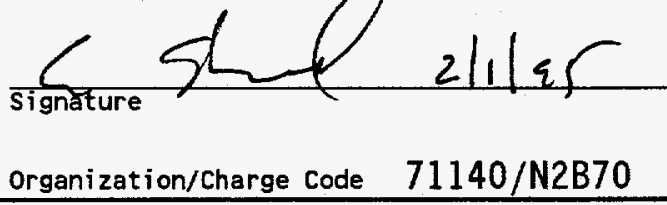

7. Abstract

This document details organization responsibilities and engineering requirements for the design and fabrication of two gas characterization systems used to monitor

flammable gas watch-list tanks.

8.

RELEASE STAMP

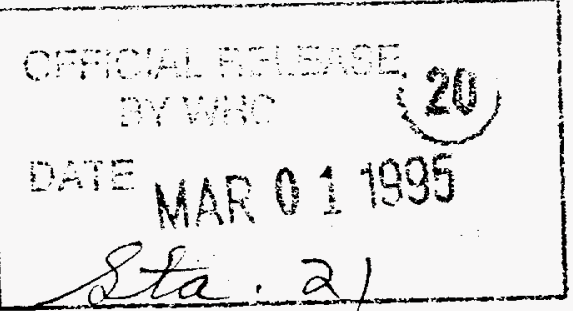




\title{
TWRS HYDROGEN MITIGATION GAS CHARACTERIZATION SYSTEM \\ DESIGN AND FABRICATION ENGINEERING TASK PLAN
}

\author{
Prepared by
}

E. K. Straalsund

TWRS Safety Special Projects

January 1995

\section{DISCLAIMER}

This report was prepared as an account of work sponsored by an agency of the United States Government. Neither the United States Government nor any agency thereof, nor any of their employees, makes any warranty, express or implied, or assumes any legal liability or responsibility for the accuracy, completeness, or usefulness of any information, apparatus, product, or process disclosed, or represents that its use would not infringe privately owned rights. Reference herein to any specific commercial product, process, or service by trade name, trademark, manufacturer, or otherwise does not necessarily constitute or imply its endorsement, recommendation, or favoring by the United States Government or any agency thereof. The views and opinions of authors expressed herein do not necessarily state or reflect those of the United States Government or any agency thereof.

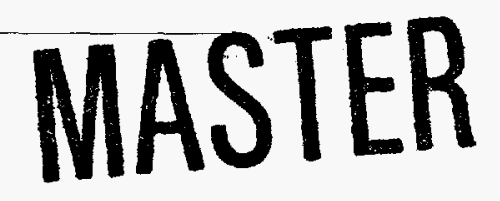




\section{CONTENTS}

1.0 INTRODUCTION .................... 3

2.0 SCOPE $\ldots \ldots \ldots . \ldots \ldots$

2.1 OBJECTIVE $\ldots \ldots \ldots$

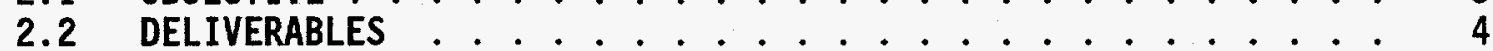

3.0 DESCRIPTION . . . . . . . . . . . . . . . . . . 4

3.1 PHYSICAL DESCRIPTION .................. . . 4

3.2 ENGINEERING TASKS ................. 4

3.3 VERIFICATION .................. . . . 5

3.4 PROCUREMENT . . . . . . . . . . . . . . 6

3.5 FABRICATION ..................... 6

4.0 ORGANIZATIONAL RESPONSIBILITIES . . . . . . . . . . . . 6

4.1 Hydrogen Mitigation .............. . . 6

4.2 TWRS Safety Special Projects . . . . . . . . . . . . . . 6

4.3 Installation/Acceptance Testing ........... . 7

4.4 TWRS Programs QA .............. 7

4.5 TWRS Fire Safety, Nuclear Safety, and Radiological Control ............... 7

4.6 General Support Projects . . . . . . . . . . . . . 7

4.7 Applications Design Services ............. 8

5.0 SCHEDULE . . . . . . . . . . . . . . . . . . 8

6.0 COST ESTIMATE . . . . . . . . . . . . . . . . 8

7.0 QUALITY ASSURANCE . . . . . . . . . . . . . . 9

8.0 SAFETY ............................. 9

9.0 REFERENCES . . . . . . . . . . . . . . . 9 
WHC-SD-WM-ETP-143

ReV. 0

PAGE 3

\author{
TWRS HYDROGEN MITIGATION \\ GAS CHARACTERIZATION SYSTEM \\ DESIGN AND FABRICATION ENGINEERING TASK PLAN
}

\title{
1.0 INTRODUCTION
}

The flammable gas watch-list (FGWL) tanks, which have demonstrated a gas release event (GRE) exceeding $0.625 \%$ hydrogen by volume wi1l require additional characterization. The purpose of this additional characterization is to accurately measure the flammable and hazardous gas compositions and resulting lower flammability limit (LFL) of the tank vapor space during baseline and GRE emissions. Data from this characterization will help determine methods to resolve the unreviewed safety question (USQ) for the FGWL tanks. This task plan details efforts to support this characterization by fabricating gas characterization systems based upon proven designs used in Tank 241-SY-101.

The vapor monitoring instruments to be installed in the gas monitoring system will allow accurate analys is of the tank vapor. It will be possible to accurately measure a wide range of hydrogen from parts per million to percent by volume, as well as other gas species suspected to be generated in FGWL tanks.

\subsection{SCOPE}

\subsection{OBJECTIVE}

This task plan details organizational responsibilities and requirements for the design, technical documents, fabrication, and testing of gas

characterization systems. The installation and operation of these GCS systems will be detailed under a separate engineering task plan. The GCS will consist of six major components: test facility, sample gas delivery system, sample gas analytical system, grab sample system, support gas system, and stand-alone data system. The test facility will provide an environmentally controlled facility to house scientific equipment for the analysis of the waste tank vapor space gases. The gas monitoring building will be similar to the unit used for the GMS-2 gas monitoring facility on 241-SY-101. The sample gas delivery system will provide a gas sample to the analytical system. The sample gas analytical system will be capable of measuring a wide range of hydrogen $\left(\mathrm{H}_{2}\right)$ concentrations and a variety of other suspected gas species from $1 \mathrm{ppm}$ to $3 \%$ by volume, specifically methane $\left(\mathrm{CH}_{4}\right)$, nitrous oxide $\left(\mathrm{N}_{2} \mathrm{O}\right)$, and ammonia $\left(\mathrm{NH}_{3}\right)$. The grab sample system will allow independent lab verification of the GCS measurements plus identification of other species not being monitored. The support gas system provides the analytical instruments' carrier and purge operating gases plus provides automatic instrument calibration using certified gases to ensure data validation. The stand-alone data system will perform the data analysis of the analytical system data, display selected data, and archive this data both $10 \mathrm{ca} 71 \mathrm{y}$ and provide selected data outputs to a LAN. 


\subsection{DELIVERABLES}

The following items shall be prepared:

1. Drawings for system fabrication and installation:

- Drawing index tree

- Facility arrangement

- Civil/structural

- Electrical one-line and elementary diagrams

- $\quad$ Piping and instrument diagram

- $\quad$ GCS assembly drawings

- Tubing routing

- Instrumentation wiring diagram

- Loop diagrams

- Block diagram for the data system and HLAN within GCS

2. Supporting documents:

- Test plans and procedures

- Test reports

- Design description

- Design analysis

- Safety assessments/letters of applicability

- Software documentation

3. Vendor information file

4. As-built documentation drawings on task completion

5. Two fully-tested and ready-to-install gas characterization systems

Approved $\mathrm{H}$-series drawings will be issued prior to GCS installation on the selected tanks.

\subsection{DESCRIPTION}

\subsection{PHYSICAL DESCRIPTION}

The Gas Characterization System (GCS) will contain two dual-column gas chromatographs (GCS) and one FTIR. The GCS and FTIR will provide monitoring for a broad range of hydrogen $\left(\mathrm{H}_{2}\right)$, methane $\left(\mathrm{CH}_{4}\right)$, ammonia $\left(\mathrm{NH}_{3}\right)$, and nitrous oxide $\left(\mathrm{N}_{2} \mathrm{O}\right)$ concentrations from $1 \mathrm{ppm}$ to $3 \%$ by volume. The sample gas analytical system will provide local display of analyzed sample gases, as well as both local and remote data logging capabilities through a high-speed data link. Functional requirements for the GCS are detailed in WHC-SD-WM-FDC-041, "Gas Characterization System Functional Design Criteria."

\subsection{ENGINEERING TASKS}

1. Prepare drawings for fabrication of GCS.

2. Procure the required equipment and materials. 
3. Prepare plant forces work review.

4. Coordinate fabrication of the GCS.

5. Prepare test procedures.

6. Conduct and witness testing of equipment.

7. Prepare design calculations.

8. Prepare and release test reports (completed test procedures).

9. Prepare and release design description.

10. Prepare and release safety assessments.

11. Prepare and release computer software documentation.

The design and fabrication will be controlled in accordance with "Engineering Practice Guidelines," WHC-IP-1026, EPG-2.0, "Engineering System Design Control." Changes to the design documentation during fabrication will be by the ECN process initiated by the cognizant engineer. The design drawings plus the ECNs issued during the fabrication will provide as-built documentation. Following fabrication, the system will be tested to verify compliance with the design.

Each GCS will be assigned a specific facility destination and will be coordinated with the installation drawings for that facility.

Computer software purchased and written for the operation of the gas chromatographs and the FTIR will be prepared and controlled in accordance with WHC-CM-3-10, "Software Practices," SP-3.0, "Development," and SP-6.0, "Configuration Control." The GC and FTIR operation will use commerciallyavailable software. Software will be developed as necessary for the interface of the FTIR and GC with the stand-alone data acquisition system.

\subsection{VERIFICATION}

An informal design review will be held prior to the issuance of the $\mathrm{H}$-series drawings for fabrication, thus allowing interested parties to have input to the system design. Copies of the final drawings will be provided to the review team for information at the time the drawings are issued for fabrication. The fabrication will be subject to monitoring and inspection by the cognizant engineer or his designee. The fabrication will be inspected by the cognizant engineer prior to verification testing.

The design will be verified by acceptance testing. Acceptance testing will be performed in the fabricator's shop and witnessed by the cognizant design engineer and the cognizant quality engineer. The cognizant engineer may elect to have additional personnel witness the testing.

Computer software will be validated by testing. Requirements, test procedures, and validation requirements will be issued for the required software per the requirements of WHC-CM-3-10, "Software Practices." The equipment being controlled and/or operated by personal computers shall pass the validation testing prior to being placed in operation. 


\subsection{PROCUREMENT}

Long-lead items will be purchased by WHC and provided to the fabrication contractor for assembly and installation into the GCS. The material being provided to the fabrication contractor will be identified in a formal letter of instruction (LOI) prior to the start of fabrication.

The remaining material will be purchased by the construction contractor.

The required computer software will be purchased and installed by the operating contractor prior to operational testing.

\subsection{FABRICATION}

The GCS building will be fabricated using engineering drawings controlled in accordance with WHC-IP-1026, "Engineering Practice Guidelines," EPG-2.0, "Engineering System Design Control."

\subsection{ORGANIZATIONAL RESPONSIBILITIES}

The task responsibilities are outlined in the following sections.

\subsection{Hydrogen Mitigation}

Project Manager: JW Lentsch

- Plan and coordinate overall program.

- Approve engineering documentation.

- Approve design criteria.

\subsection{TWRS Safety Special Projects}

Cognizant Manager:

Team Leader:

Cognizant Engineer:
RE Bauer

EK Straalsund

TC Schneider

- Provide cost and schedule estimates (no funding control).

- Design and coordinate fabrication, assembly, and installation of the gas characterization systems.

- Coordinate onsite component fabrication.

- Prepare acceptance test procedures and perform acceptance testing as required.

- Provide system fabrication and installation engineering support.

- Support preparation of system engineering installation requirements documents.

- Support installation design activities, as required.

- Support engineering documentation as-building, review, and release process.

- Support preparation draft system maintenance and operations procedures.

- Support field operation and system maintenance. 
- Support maintenance and operations system training.

\subsection{Installation/Acceptance Testing}

Manager: RW Reed

Cognizant Engineers: As Assigned

- Will act as the cognizant engineer or cognizant manager on behalf of Systems Engineering, as the design authority and customer for Waste Tank Upgrade Installation/Testing (WTUI/T) WTPE for all structures, systems, and equipment (SSE) provided for this project.

- Will advise, review, and approve applicable SSE: functional and design criteria, design, description, training, operation, maintenance, and safety documents.

- Will define what is required for "Acceptance for Beneficial Use" (ABU).

\subsection{TWRS Programs QA}

Manager:

DC Board

Cognizant Engineer: ML McElroy

- Review and approve the fabrication and installation documents, work plans, and work instructions, as required.

- Perform the necessary surveillance and inspection activities to assure conformance to the appropriate documents and procedures throughout fabrication and installation.

- Review and concur with impact level and safety class designations.

- Support the system readiness review process.

- Provide acceptance documentation (green tag) for the system field installations.

\subsection{TWRS Fire Safety, Nuclear Safety,} and Radiological Control

Manager:

MN Islam

Cognizant Engineer: . LS Krogsrud

- Review and approve the fabrication and installation documents, work plans, work instructions, and test procedures and reports, when required.

- Review and concur with impact levels and safety class designations.

- Coordinate all required safety reviews, including industrial health and safety, fire safety, nuclear safety and radiological control.

\subsection{General Support Projects}

Project Manager:

Project Engineer:
JB Witt

As Assigned 
- Provide fabrication support services as required for the gas characterization system.

- Preparation of appropriate documents and procedures throughout fabrication operations.

\subsection{Applications Design Services}

Cognizant Manager: RO Skorge

- Provide design support services as required for the gas characterization system. Anticipated support activities includes generation of fabrication drawings and installation drawings.

\subsection{SCHEDULE}

Following are the task milestones:

Complete fabrication drawings

Complete procurement

Complete shop fabrication of GCS

Complete verification testing

Complete design documentation

Task complete

May 12, 1995

JuT 17, 1995

Sep 13, 1995

Oct 4,1995

Oct 4,1995

Oct 4, 1995

These are the final completion dates for the design and fabrication. The design documents and drawings will be issued prior to fabrication.

\subsection{COST ESTIMATE}

WHC Engineering Support

TWRS Safety Special Projects

Equipment Procurements

$\begin{array}{ccc}\text { MANHOURS } & \text { CHARGE } \\ \text { COST } & \text { CODE }\end{array}$

Equipment Procurements

General Support Projects W.0.

9,300

$\$ 558,000$

71140

562,000

$\$ 25,000$

$7 F 510$

Standards Lab. W.0.

$\$ 10,000$

$8 D 660$

PNL Gas Analysis W.0.

$\$ 10,000$

D7E21

Design and Fabrication

ICF KH Design

Fabrication

$\$ 100,000$

270,000

57570

Total Cost

$\$ \longdiv { 1 , 5 3 5 , 0 0 0 }$ 


\subsection{QUALITY ASSURANCE}

The design documents generated for this task will be prepared and verified in accordance with WHC-IP-1026, "Engineering Practice Guidelines," EPG-2.0, "Engineering System Design Control," and WHC-CM-3-5, "Document Control and Records Management Manual, "Section 12.7, Rev.0, "Approval of Environmental, Safety, and Quality Affecting Documents". This task has been identified as Approval Designator SQ in accordance with Section 12.7. The work associated with this task plan will meet the requirements of the Quality Assurance Project Plan as outlined in WHC-EP-550, "Project Plan for Mitigation," and WHC-CM-4-2, "Quality Assurance Manual."

\subsection{SAFETY}

This system is Safety Class 3 in accordance with the requirements of WHC-CM-4-46, "Nonreactor Facility Safety Analysis Manual," and WHC-CM-1-3, "Management Requirements and Procedures," MRP-5.46, "Safety Classification of Systems, Components and Structures." Safety assessments will be prepared and approved prior to operating this system.

\subsection{REFERENCES}

1. WHC-SD-WM-FDC-041, "Gas Characterization System, Functional Design Criteria."

2. WHC-CM-1-3, "Management Requirements and Procedures."

- MRP 2.16, "Controlled Manual System, Paragraph 5.0, Requirements."

- MRP 5.46, "Safety Classification of Systems, Components and Structures."

3. WHC-CM-3-5, "Document Control and Records Management Manual."

- Section 12.7, Rev. 0, "Approval of Environmental, Safety, and Qual ity Affecting Documents."

4. WHC-CM-3-10, "Software Practices."

$$
\text { - SP-3.0, "Development." }
$$

5. WHC-CM-4-2, "Qual ity Assurance Manual."

6. WHC-CM-4-46, "Nonreactor Facility Safety Analysis Manua1."

7. WHC-CM-6-1, "Standard Engineering Practices."

- EP-1.3, "Preparation of Engineering Drawings."

- EP-1.7, "Engineering Document Approval and Release."

- EP-2.2, "Engineering Document Change Control Requirements."

- EP-3.3, "Vendor Information."

- EP-4.1, "Design Verification Requirements."

- EP-4.2, "Testing Practices."

- EP-5.8, "Engineering Document Contents."

8. WHC-EP-550, "Project Plan for Mitigation." 
9. WHC-IP-1026, "Engineering Practice Guidelines."

- EPG-2.0, "Engineering System Design Control."

10. General

- DOE Order 6430.1a, "General Design Criteria."

- NFPA-70, "National Electrical Code."

- ANSI/ISA-RP12.6, "Installation of Intrinsically Safe Systems for Hazardous Locations." 